\title{
Analysis of the Jurisdiction of the Courts of First Instance of Turkey
}

\author{
Ravil R. Zainashev ${ }^{1}$, Idris M. Gilmanov ${ }^{1} \&$ Muhamat M. Gilmanov ${ }^{1}$ \\ ${ }^{1}$ Kazan Federal University, Russia \\ Correspondence: AAmini Abdul Rahman, Kazan Federal University, Russia. E-mail: muhamat74@yandex.ru
}

Received: June 9, 2019

Accepted: August 25, $2019 \quad$ Online Published: August 31, 2019

doi:10.5539/jpl.v12n5p79

URL: https://doi.org/10.5539/jpl.v12n5p79

\begin{abstract}
The article presents three periods from the history of the legal system of Turkey, the knowledge of which will allow for objective scientific research. Indeed, each period has contributed to the development of the judicial system. Of particular importance will be the attitude of the legislator to the justice of the peace in criminal matters with a maximum sentence of up to 1 year in prison. The latter since 2014 were abolished and their load was redistributed to a higher authority. France did likewise, which also rejected justice of the peace.

In addition, this study addresses the issues of the accelerated process, which was either introduced or canceled. In Russia, a simplified legal procedure has been successfully applied. Most European countries apply simplified the legal procedure to criminal offenses for which the maximum sanction of punishment is up to five years in prison. In Turkey, a simplified legal procedure was applied to criminal offenses with a maximum sentence of up to 2 years in prison. Despite a small sanction and tendencies in other countries to introduce simplified procedures, the Turkish legislator refused this practice.
\end{abstract}

Keywords: the courts of the first instance, the analysis of jurisdiction, the justice of the peace, the judicial system of Turkey, the criminal-civil courts of justice, the lowest level of the courts of justice

\section{Introduction}

Russia continues its judicial reform, and therefore materials on the judicial systems of other states are of no small importance. The obtained results can be used in solving certain issues arising in the formation of the national judicial system. The judicial system of Turkey will be taken as comparative material. Moreover, Turkey, a member of NATO, and Russia, after the fact of the destruction of the Russian military aircraft during the liberation of Syria, have reestablished their relations. At the same time, Vladimir Putin and Recep Erdogan resolve many international issues in concert. The World Cup held in July 2018 in our country promoted change towards a positive attitude towards Russia.

Before starting to study the judicial system of Turkey, it is necessary to begin with the history of the legal system of this country, which has three periods. This fact indicates that the legal system of Turkey is rich in experience, the study of which is always useful. Indeed, if Russia tries to forget, and will not study the past experience of its country, as well as the experience of other countries, this will be an unforgivable mistake.

As for tsarist Russia, the period from 1864, when the justice of the peace was introduced and functioned in the country, was of great interest. The national legislator was primarily faced with the choice whether to introduce a new lower court, if so, determine their jurisdiction, coordinate it with the competence of city and district courts. In our opinion, the legislator successfully coped with this task at that time.

The jurisdiction of the justices of the peace included criminal cases of crimes with a maximum sentence of up to 1 year in prison. A quarter of a century later, in 1889, this "threshold" was increased to 1 year 6 months. In the modern period, criminal cases with maximum sanction up to 2 years of imprisonment, which was further increased to 3 years, belonged to the jurisdiction of the justice of the peace. Apparently, the modern Russian legislator is not going to return to the pre-revolutionary "threshold". And this despite the ever-increasing load of justices of the peace, which is objective. In this regard, the legislator should develop draft laws on the timely determination of the jurisdiction of the courts of the first instance in advance.

\section{Materials and Methods}

The empirical material for writing this article was the comparative procedural method of studying the regulatory legal acts of the Russian Federation; a brief analysis is presented taking into account the previously adopted 
procedural laws. To use the comparative method, we used the collected material on the jurisdiction of the courts of the first instance in Turkey. At the same time, the important point is that until the middle of 2014, justice of the peace for criminal cases functioned in this country, whose jurisdiction included criminal cases with up to 1 year in prison. However, in a separate law, the justice of the peace was abolished in criminal matters. Consequently, the freed load of the justice of the peace must be redistributed, which is a difficult task for the national legislator. This means that it is necessary to provide for additional staff of district (city) judges, the number of which follows from the size of the state budget. Rational combination of one with the other is not always possible. Moreover, if the principle of rationality is violated, then this affects the emergence and growth of tension in society.

The information given in this study on the Russian judicial system related to the activities of justice of the peace will allow us to proceed to the analysis of jurisdictional issues inherent in the Turkish judicial system.

\section{Results and Discussion}

The history of the Turkish legal system is rich and can be divided into three periods. The first period is until 1839, distinguished by the rule of Muslim law. This period includes the adoption by the Ottoman caliphs and the promulgation of laws, the so-called "Kannunam," relating to criminal law regulations (Tanzimat).

The second period was from 1839 to 1918, when attempts were made to reform Muslim law on the model of European laws. It was then that the national legislator when formulating his criminal code, took the French Penal Code of 1810 as a basis. As a result, a new Criminal Code was adopted in the Ottoman Empire. Similar work was carried out during the formation of the new Criminal Procedure Code. The CPC of France was taken as a basis, and in 1879 the new CPC was adopted.

The third period was marked by a significant westernization of Turkish law. As a result of the revolution of 1920-1923, Kemal established a new Turkish state. The development of the legal system was first aimed at its complete de-Islamization. To facilitate the work of the legislator, the codes of France, Germany, Italy, and Switzerland were taken as a basis. If we take the criminal law, it can be noted here that the new Criminal Code was almost completely formed on the basis of the Italian Penal Code of 1889. The new Criminal Procedure Code was drawn up on the basis of the German Criminal Procedure Code of 1872. Thus, in 1926, Turkey became part of the Roman-German legal system.

A feature of the modern period of development of Turkey is its secular nature. It is important to note that any attempts to raise the issue of revising and returning to Islamic spiritual traditions are flatly suppressed by the current government under the leadership of President Recep Erdogan.

Turning directly to the history of the creation of criminal legislation, it is necessary to recall that in 1840 the Ottoman Empire adopted the Criminal Code almost completely borrowed from the French Criminal Code of 1810. Indeed, this document preceded the new Criminal Code of 1926, which was drawn up on the basis of the Italian Criminal Code of 1889 .

However, to replace the latter, a draft of the Turkish Criminal Code was prepared. This project was distinguished by a decrease in liability for ordinary crimes, and sanctions for committing political crimes were tightened. The preparation of this draft Criminal Code was completed in 1997. According to the requirements of Article 11 of the Criminal Code, offenses are divided into crimes and misconduct. The latter entailed punishment in the form of light imprisonment, i.e. imprisonment for a period of one day to two years (Article 21 of the Criminal Code). This category of criminal cases was transferred to the jurisdiction of the sole judge of the main courts (aslie) operating in provincial centers and in large cities. Thus, the jurisdiction of the courts of the first instance in criminal cases includes criminal cases with a maximum term of punishment of up to 5 years in prison.

The Turkish Code of Criminal Procedure (Ceza Muhakemelleri Usulu Kanunu CMUK) No. 1412 was adopted on April 20, 1929. The content was a translation of the German Code of Criminal Procedure in 1872. On June 8, 1936, the legislator adopted Law No. 3005, which regulated the special procedure of "egregious offenses". However, this law was repealed in 2005.

The Criminal Procedure Code of 1872 was replaced by the Criminal Procedure Code of 2005. The latter provided for a "mixed system" of criminal proceedings. This means that the preliminary investigation and preparation of the contents of the public prosecution was carried out as part of the "inquisition system", and the judicial investigation was conducted in public.

Courts of general jurisdiction are divided into criminal and civil courts. The latter can be immediately clarified that the functions of lower courts in civil cases are performed by the justice of the peace (literally in English, Justice of the World). Criminal courts were divided into three categories: general criminal courts, special chambers (or sections) of courts of general jurisdiction, and criminal courts with special status. Prior to the abolition, justices of 
the peace were established in the administrative centers of ilche (districts) and acted in almost every bujak (volost). As indicated above, their jurisdiction included the consideration of criminal cases with a maximum sentence of up to one year in prison.

It is important to pay attention to the attitude of the legislator towards the simplified procedures. Since May 2011, the participation of prosecutors in trials using simplified procedures was canceled in Turkey. However, at the end of 2013, prosecutors were returned to the courtrooms and simplified procedures were canceled.

In addition, Article 286 of the CPC of Turkey provides for the possibility of appealing against sentences of criminal chambers of district courts, with the exception of their orders to annul decisions. The second part of this article provides a list of certain cases that are also not subject to appeal. In particular, this list contains acquittals in criminal cases with an estimated maximum sentence of up to 10 years in prison or in the form of a fine.

Jurisdiction of criminal courts in Russia is regulated by Article 31 of the CPC. It sets out a list of crimes provided for in the Criminal Code of the Russian Federation, with a maximum sanction of not more than 3 years in prison. Until July 1, 2002, this was equal to two years. Further, on December 7, 2011, the Russian legislator changed the content of Article 15 of the Criminal Code and increased the maximum sanction for minor crimes from two to three years in prison. Simplified procedures in the Criminal Procedure Code of the Russian Federation are provided for by Section 10 "Special Procedure for Trial". It consists of two chapters: 40 "Special Procedure for Taking a Court Decision if the AccusedAgrees with the Charge Brought Against Him" and 40.1 "Special Procedure for Making a Judicial Decision when Concluding a Plea Agreement". The requirements of these chapters, allowing the court to make a decision without a trial, can be applied under certain conditions: for a committed crime of the Criminal Code, a punishment of not more than 10 years of imprisonment is provided, if the accused agrees with the charge brought against him, is aware of the nature and consequences of his application, which is stated voluntarily and after consultation with counsel.

\section{Summary}

A comparative analysis of the jurisdiction of the courts of the first instance in Turkey and Russia allows us to identify both trends and features inherent in them. In 2014, Turkey, like France in 1958, abolished the lower court - justice of the peace for criminal cases, who dealt with criminal cases up to 1 year in prison. This burden was transferred to the higher-level federal judges. In our opinion, this approach does not eliminate the existing problem. This is comparable to the fact that the problem was "cornered" but not resolved.

\section{Conclusion}

The Turkish legislator's approach to resolving issues of jurisdiction of the courts of the first instance shows that the chosen path did not solve the problem. It is obvious that the legislator will have to return to the restoration of justice of the peace in criminal cases, as well as restore their jurisdiction - up to one year in prison. However, the Russian legislator, apparently, also needs to return the maximum punishment imposed by the justice of the peace from 3 to 2 years in prison, since the load of the latter is constantly growing.

In addition, the Turkish legislator needs to return simplified proceedings, which would facilitate the work of the courts and speed up the consideration of criminal cases with little punishment. Such a return would significantly save expenditures from the country's budget.

\section{Acknowledgements}

The work is performed according to the Russian Government Program of Competitive Growth of Kazan Federal University.

\section{References}

Ansay, T., \& Wallance, D. (2011). Introduction to Turkish law (6th ed.). Oceana New York.

Enisey, F. (2015). Criminal Procedure Law in Turkey. Retrieved from https://law.ku.edu/files/docs/istanbul/criminal-procedure-istanbul-20156.pdf

Gyurelli, N. (1983). The recent development of the Turkish criminal procedure and the practice of the Turkish judicial system.

Kolokolov, N. A., Pavlikov, S. G., \& Sachkov, A. N. (2008). World Justice: Textbook. The allowance. UNITY-DANA: Law and justice.

The Criminal Code of the Russian Federation. M.: Prospekt, 2018.

The Criminal Code of the Russian Federation. M.: Prospekt. 2012. P. 14-19. 
The Criminal Code of Turkey. Retrieved from http://www.basha.lv/?wp=398\&lg=1

The Criminal Procedure Code of the RSFSR. M.: Prospekt. 2000. P. 21, 205.

The Criminal Procedure Code of the Russian Federation. Prospekt. 2018. P. 28-29.

\section{Copyrights}

Copyright for this article is retained by the author(s), with first publication rights granted to the journal.

This is an open-access article distributed under the terms and conditions of the Creative Commons Attribution license (http://creativecommons.org/licenses/by/4.0/). 